\title{
ON THE ZERO VIEWPOINT IN DRAMA
}

Keywords: drama, viewpoint, perspective, narration

Słowa kluczowe: dramat, punkt widzenia, perspektywa, narracja

There is nothing more trivial than stating that the categories of perspective and viewpoint are indispensable in the poetics of drama. All the same, one of the most controversial claims for many contemporary drama analysts is that perspective can be the key to solving the riddle of narration in drama. Nevertheless, I have decided to pose the question concerning the relations between perspective, narration, and drama.

I believe that the existing body of research on the category of viewpoint in drama makes such a question wholly legitimate. Researchers who have decided to explore this problem constantly employ this category in order to demonstrate the presence of various forms of epic passages in the "dramatic element." One of these researchers, Edward Groff, proposes to discuss viewpoint in three areas: demonstrations of the character's inner life, projections of dreams, and narratorial interventions. ${ }^{1}$ The last, in particular, serve to identify epic elements in drama. This solution is close to the notion of frame narrator, a notion used by Brian Richardson. ${ }^{2}$ The researcher points to the textual exponents of this form of presence particularly in the prologues, epilogues, and other sections addressed ad spectatorem. What is particularly interesting for my study here is his claim that the position of a frame narrator is characteristic of most dramas. This conclusion, which I approach as a research thesis, should, however,

\footnotetext{
${ }^{1}$ E. Groff, "Point of View in Modern Drama," Modern Drama, no. 3 (1959).

${ }^{2}$ It should be observed that the relation between different types of narrators (internal, monodramatic, generative narrator) as differentiated by Richardson is not quite clear. See B. Richardson, "Voice and Narration in Postmodern Drama," New Literary History, no. 32 (2001); idem, "Narrative and Drama," in Cambridge Companion to Narrative Theory, ed. D. Herman (Cambridge: Cambridge University Press, 2007).
} 
be radicalised, i.e. the position discussed by Richardson, rather than merely being characteristic of most stage dramas, may turn out to be constitutive of drama in general.

At first glance, his hypothesis might seem utterly unjustified, as literary studies have maintained the traditional Platonic-Aristotelian ${ }^{3}$ distinction between the dramatic and narrative modes of story-telling. Out of this division, the $20^{\text {th }}$-century predecessors of Franz Stanzel derived their traditional taxonomy which defines the so-called scenic presentation and reportorial narration ${ }^{4}$ Leaving aside all doubts that such a differentiation might provoke, ${ }^{5}$ it should be stressed that when referring to drama (and scenic presentation as related to it), we tacitly tend to assume that the addressee positions him- or herself outside the world created by the author. Most traditional theories concerning the poetics of drama are based on this kind of assumption. ${ }^{6}$ It was not until $20^{\text {th }}$-century stage experiments were analysed that the possibility of a different solution was discovered; namely, admitting the audience into the world represented in the drama ${ }^{7}$ by assigning the dominant role to the viewpoints of selected persons of the drama. The perspective of a researcher studying the notion of viewpoint in drama would then be as follows: either to focus on an analysis of the audience perspective in "traditional" drama - which is external to the world of the drama - or to look for manifestations of a dramatic person's individual voice in the plays of the $20^{\text {th }}$ - and $21^{\text {st }}$-century avant-garde.

The former approach is indelibly flawed as it ignores an important element that is characteristic of dramatic genres and related to the process of building a "framework" for the represented world. Contemporary research proves that what lies at the source of this narrative textual mode is, even in classical drama, the speech of the stage character. ${ }^{8}$ The elucidation in recent years

\footnotetext{
${ }^{3}$ See A. Gaudreault, From Plato to Lumière: Narration and Monstration in Literature and Cinema, trans. T. Barnard (Toronto: University of Toronto Press, 2009).

${ }^{4}$ The most important publications include: S. Chatman, Story and Discourse. Narrative Structure in Fiction and Film (Ithaca: Cornell University Press, 1978); M. Fludernik, Introduction to Narratology (Abington: Routledge, 2009); R. Linhares-Dias, How to Show Things with Words. A Study on Logic, Language and Literature (Berlin: Mouton de Gruyter, 2006); P. Lubbock, The Craft of Fiction (London: Jonathan Cape, 1954); S. Rimmon-Kenan, Narrative Fiction: Contemporary Poetics (London: Routledge, 2005); M. Toolan, Narrative: A Critical Linguistic Introduction (London: Psychology Press, 2001).

${ }^{5}$ The telling/showing differentiation was criticised by Wayne C. Booth. See W. C. Booth, The Rhetoric of Fiction (Chicago: University of Chicago Press, 1983), 154-155.

${ }^{6}$ See P. Szondi, Theory of Modern Drama, trans. M. Hays (Cambridge: Cambridge University Press, 1987).

${ }^{7}$ From among the Polish authors, the works of Tadeusz Różewicz are particularly important in this context. See R. Cieślak, Widzenie Różewicza (Warszawa: Wydawnictwa Uniwersytetu Warszawskiego, 2013), in particular the chapter: Język czy obraz? Spór o prymat.

${ }^{8}$ See R. Barthes on the works of Racine: R. Barthes, Sur Racine (Paris: Editions du Seuil, 1963).
} 
of issues related to the so-called internal stage directions is one of the best examples of this. ${ }^{9}$

As far as the second stance is concerned, the very claim that the reader was not introduced inside the presented world until the age of neo-Romanticism is dubious. The results of studies conducted by Latin American researchers suggest that this kind of possibility was present in drama at least since the time of Calderon. The phenomenon of decorado verbal, ${ }^{10}$ which is characteristic of $16^{\text {th }}$ - and $17^{\text {th }}$-century plays, provides proof for the potential of dramatic form with regard to revealing the perspective of a particular person of the drama. The layer of dramatic background, indispensable to those kinds of works, should be perceived as a sign of resistance against a complete "internalisation" of drama by the text itself.

The combination of doubts regarding unambiguously determining the addressee's position with the problems of narrativity that recur in writings on viewpoint in drama has led me to suggest a new way of defining the specific qualities of drama as a literary kind. It lies at the intersection of dramatic background and the protagonist's perspective, and therefore seems natural for drama to position the addressee not simply outside or inside the dramatic microcosm but at the point of a permanent intersection of these two lines. A similar idea was put forward by Tadeusz Kowzan, although first he assumed that the addressee would constantly be moving between these two perspectives, and, second, a full manifestation of this phenomenon would only be possible during a theatrical performance. ${ }^{11}$ I myself believe that there is also potential in the text itself and would therefore like to focus on an analysis of the moments of intersection or overlap of these two perspectives. Their combination - which can be defined as a zero point of view - is in my view the genuinely narrative situation that we encounter in the dramatic art.

I will consider this zero point of view as evidence for the existence of a higher level of intratextual level of communication in drama. The intersection of two functional and situational roles - those of internal director and internal

${ }^{9}$ T. Gallèpe, "Didascalies internes et construction de la représentation: l'exemple de 'Napoleon oder die hundert Tage' de Chr. D. Grabbe," Nouveaux Cahiers d'Allemand. Reuve de linguistique et de didactique, no. 1 (2006); J. Laillou Savona, "La didascalie comme acte de parole," in Théâtralité, écriture et mise en scène, ed. J. Féral, O. Aslan, J. Laillou Savona, E. A. Walker (Brèches Hurtubise HMH, 1985); J. Laillou Savona, "Narration et actes de paroles dans le texte dramatique," Études littéraires, no. 3 (1980).

${ }^{10}$ I. Arellano, "Valores visuales de la palabra en el espacio escénico del Siglo de Oro," Revista Canadiense de Estudios Hispánicos, no. 3 (1995); M. C. Bobes Naves, "Texto literario y texto espectacular en El caballero de Olmedo,” Cuadernos de Teatro Clásico, no. 1 (1988).

${ }^{11}$ T. Kowzan, "Teatr w teatrze czyli o dialektyce iluzji scenicznej," Dialog, no. 4 (1971); idem, Znak i teatr (Warszawa: Polskie Towarzystwo Semiotyczne, 1998). 
viewer $^{12}$ - defines the dramatic message, the very non-dit that was described by Anne Übersfeld. No other literary kind highlights this conflict, or rather specific filiations between utterance and the situation in which it is produced, as distinctly as drama. Drama, in this context, opens up the possibility of analysing that "self-observing eye" that is so frequently evoked in philosophical and literary thought.

\section{The dramatic eye}

In one of his best-known studies on gaze titled Anamorphosis, Jacques Lacan described a subject who "sees himself seeing himself."13 The French philosopher thus reiterated the question concerning the possibility of properly defining the relation between the gaze and sight (eye) of the viewer. Drawing on studies by Jean-Paul Sartre, Jurgis Baltrušaitis, and indirectly also Søren Kierkegaard, he undertook to describe not so much the relation between image and object as between image and the so-called geometral point. Lacan thus focused on the relation between the line of gaze and the human sight that organises it. The ground for this research is the image itself: as the source, basis, and centre of perception.

Should one wish to look for the grounds on which the relation Lacan was interested in could reveal itself in drama, one should point to the diegetic context of the utterance. The background that is organised by it should be treated as a result of the distance between the dramatic subject and the stage image created by the text, and as a necessary condition for the occurence of such dissonance. The background, as Maurice Blanchot seems to state, is what pushes us away from the image but also allows us to observe it. ${ }^{14}$

One of the constitutive features of drama as a literary genre is that it is made up of two components, and thus each drama works on two levels. This double type of communication is therefore inscribed into the structure of the text due to the combination of the stage directions and dialogues that define this genre. Stage directions and dialogues reflect the relation between the act of speaking and the conditions in which something is spoken, between mimesis and diegesis. In other words, in drama the addressee is confronted with two viewpoints: one proper to dialogue and the other organised by the stage directions supplementing

${ }^{12}$ The crucial importance of these two competences for the semantic figure of spectacle which lies at the foundation of the communicative structure of drama was emphasised by D. Ratajczakowa, "Sługa dwóch panów: dwoisty żywot dramatu," Teksty Drugie, nos. 5-6 (1990).

${ }^{13}$ J. Lacan, "Anamorphosis," in idem, The Four Fundamental Concepts of Psychoanalysis, trans. A. Sheridan (New York: W.W. Norton \& Company, 1998).

${ }^{14}$ M. Blanchot, The Space of Literature, trans. A. Smock (Lincoln: Univesity of Nebrasca, 1989), 46. 
what is said on the stage. Problems begin when we attempt to unequivocally define the "owners" of these two perspectives existing within the dramatic structure. In theory, one viewpoint belongs to the presented world: it originates within the boundaries of that world, emerges from the speech of the persons that move within it, and, finally, guarantees the existence of that microcosm. The other perspective belongs to the author, enunciator, scriptor, presenter, the speaking voice, ${ }^{15}$ the dramatic subject - to list just a few of the possible descriptions of the owner of the "discourse of stage directions."

On the one hand, dramatic and theatrical practice proves that situating the author's viewpoint unequivocally in the stage directions, in the space of discourse, in the dramatic context of "the act of speaking" - is untenable. ${ }^{16}$ In analytical practice, it is just as difficult to clearly distinguish between the fictional world, the dramatic microcosm, and the macrocosm in which communication proper between the author and the addressee is said to be taking place. ${ }^{17}$ On the other hand, this duality of the "dramatic eye," of dramatic worlds, and consequently also of communication - is irremovable from the dramatic art. Analyses of French dramas from as early as the $17^{\text {th }}$ century prove that despite the postulate of textual homogeneity and minimalisation of the role of stage directions (to the point of completely doing away with them ${ }^{18}$ ), this duality of speech and the conditions of speaking undeniably also exists in these works.

While I agree with all of the claims as discussed above, I cannot help feeling that the research hypotheses presented here have led to a kind of stalemate. Accepting the duality, along with realising the impossibility of establishing clear boundaries between the two areas in order to draw a line of demarcation between them, is bound to make a drama analyst feel helpless. However, it seems that in the analysis of contemporary drama there is a category that may throw a new light on the problem I have just presented, namely, the category of viewpoint. ${ }^{19}$

${ }^{15}$ M. Issacharoff, "Voix, autorité, didascalie," Poétique, no. 96 (1993).

${ }^{16}$ These kinds of conclusions are false. This is evident in, for example, the metatheatrical tricks used by $19^{\text {th }}$-century authors, for whom the utterances of the dramatis personae were just as good a space for discussing their own outlook on the world, literature, or the theatre as the stage directions discussed above.

${ }^{17}$ Most researchers studying narrativity and stage directions in drama point to the importance of this issue. See V. Lochert, L'écriture du spectacle: les didascalies dans le théâtre européen aux XVIe et XVIIe siècles (Genéve: Droz, 2009).

${ }^{18}$ This is how one should understand the thesis presented by Abbé D'Aubignac in Le Pratique théâtre, 1657.

${ }^{19}$ This refers to Tadeusz Kowzan, who wrote about zerowy znak stowa [the zero sign of the word] appearing in a theatrical spectacle once the play has been limited to almost only stage directions, with the dialogues and monologues almost completely eliminated. See T. Kowzan, "Signe zero de la parole,” Degrés, no. 31 (1982), a1-a16. 
While it is not possible to prove the duality of dramatic components and levels (apart from some extreme poetics such as, for example, that of Luigi Pirandello) through the standard process of separating the creator's point of view (the author as subject) from the created person's point of view (persons of the drama), it nevertheless seems worthwhile to consider the "moments" of overlap between these two perspectives. I define this moment as the zero point of view.

It is the zero point of view that allows dramatic narration (perceived as a space of self-observation of the process of creating the dramatic microcosm) to come into existence. Not until this moment does a space open within the dramatic structure for a subject "that observes himself." A subject that does not necessarily conceal him- or herself in the stage directions proper, or in their internal variant, or in the utterances of the dramatis personae. Instead, it is characteristically present throughout the entire dramatic composition.

This brings to mind the thought of two philosophers, distant from each other in both time and space, namely Boethius and T. S. Eliot. Boethius' comments on the etymology of the persona, and the art of the theatre associated with it, lead the contemporary scholar toward the subject of the construction of masks, since the philosopher emphasises that the prosopoa, or the relation between what is being concealed and what is concealed, is revealed not so much in the relation of a specific character to the image it creates as in the very sound of the voice resonating with the mask. ${ }^{20}$ This is how the sonus appears - this specific, amplified sound that appears when an actor puts the mask on. The key to this whole phenomenon thus lies neither in the actor nor in the mask, but in the specific space between them.

Eliot points to a similar phenomenon in his analysis of the rhetoric of Shakespeare's dramas. According to the author of Murder in the Cathedral, it surfaces at the critical moments when the protagonists see themselves in a dramatic light. ${ }^{21}$ Contemporary drama studies demonstrate that this phenomenon, highlighted by the English playwright, is characteristic of every drama. This peculiar Figurenposition assumed by the protagonists of Hamlet, Midsummer Night's Dream, or Troilus and Cressida is a consequence of drama as a specific type of a communication project.

${ }^{20}$ Anicjusz Manliusz Sewerynus Boecjusz, Traktaty teologiczne, trans. R. Bielak, A. Kijewska (Kęty: Wydawnictwo Antyk, 2001), 122-125.

${ }^{21}$ See T. S. Eliot, "Rhetoric" and poetic drama, in idem, The Sacred Wood: Essays on Poetry and Criticism (New York: Bartleby, 1999), 40-41. 


\section{Bolesław Leśmian - Skrzypek opętany [The Possessed Fiddler]: Word in silence}

Bolesław Leśmian in his "Uwagi autorskie" [Author's Notes] to Skrzypek opętany [The Possessed Fiddler] postulates that tableaux vivants be avoided in drama (particularly in mime). This hypothesis is related to his vision of mimic drama which, according to the author of Dziejba leśna [Forest Tale] should "zapełnić swe wnętrze całym bezlikiem ruchów, których pozbyliśmy się dzięki nieustannej pomocy słów. Rytm, który przeszedł do słów, na nowo niechaj do ruchów powróci" [fill the entire space with a multitude of movements, which we have disposed of since we are constantly assisted by words. Let the rhythm that sunk into words now return to the movements]. ${ }^{22}$ An analysis of the above guidelines in the context of a holistic drama project that emerges from the works of Leśmian attracts our attention to a special kind of movement that the poet is trying to initiate or restore to the dramatic art.

These demands cannot be restricted exclusively to the sphere of stage movement. The solutions applied in The Possessed Fiddler show that the peculiar rhythm that seems to permeate the entire tissue of the text emerges not merely from the projected gestures, glances/gazes and behaviour of the characters (though Leśmian himself seems to suggest this kind of interpretation in "Author's Notes") but from a particular bond that links the dramatis personae to the microcosm of the drama constructed in the course of dramatic action. The author indicates that "żywe obrazy [...] nie zawierają w sobie gry mimicznej, jeno maskują jej fatalną nieobecność" [tableaux vivants [...] do not comprise mimic play, but only camouflage its fatal absence]. ${ }^{23}$ A quick review of the functions of tableaux vivants in dramatic pieces ${ }^{24}$ confirms Leśmian's intuitions. Living pictures were used by playwrights mainly as background or compositional frames. They provided a framework for the dynamics of the drama and stabilised its reception..$^{25}$ Leśmian's critique of this type of strategy was the beginning of an experiment that led to the renewal of the dramatic process underlying the tableaux vivants - a process that has its source in the zero viewpoint.

${ }^{22}$ B. Leśmian, Skrzypek opętany, in idem, Utwory dramatyczne. Listy, ed. J. Trznadel (Warszawa: Państwowy Instytut Wydawniczy, 2012), 126.

${ }^{23}$ Ibid., 125.

${ }^{24}$ See M. Komza, Żywe obrazy: między scena, obrazem i książa (Wrocław: Wydawnictwo Uniwersytetu Warszawskiego, 1995).

${ }^{25}$ This is how Victor Hugo would use it. See A. Kowalczykowa, Dramat i teatr romantyczny (Warszawa: Wydawnictwo IBL, 1997), 142; K. G. Holmström, Monodrama, Attitudes, Tableau Vivants. Studies on Some Trends of the Theatrical Fashion 1770-1815 (Stockholm: Almqvist and Wiksell, 1967). 
The special status of The Possessed Fiddler is signalled in the opening notes: "Rzecz się dzieje w owych intermediach istnienia, gdy słów nie bywa, a wszyscy sie nawzajem rozumieja?" [The drama takes place in those interludes of existence when there are no words, and yet people understand one another]. ${ }^{26}$ The addressee is immediately confronted with a world of an uncertain ontological status: a microcosm without a framework, beginning, or end. The impact of that initial statement is not weakened even by the peculiar scenographic description that appears in (sic!) "Pierwszym przywidzeniu" [The First Illusion]. The sense of instability and of the dynamism of the scenic reality is further heightened by the final fragment of the text:

\footnotetext{
Zasłona spada powoli i po zapadnięciu zasłony - wśród ciemności - dobrzmiewają jeszcze trzy brakujące uderzenia zegara, który bije północ. Po czym - wolno klinkietom zapłonąć. / Koniec Baśni - początek niewiary [The curtain falls slowly and already it has fallen - in darkness - we hear a clock striking three more times; it is midnight. Then the side lamps are allowed to light up. / End of the Tale - beginning of disbelief]. ${ }^{27}$
}

Wiktor Wołowski claims that the main function of the framework in The Possessed Fiddler is to define to what extent this work belongs to the category of fiction. According to this author, the story of Alaryel and Chryza "ujęta została w kleszcze dwóch didaskalii obalających jakby fikcyjność utworu, wyrzucających bajkę poza bajkowość, poza świat dzieła i resytuujących przygodę Alaryela w codziennych realiach cierpień i rozterek podmiotu twórczego" [was contained in the framework of two stage directions as in the forceps that in a way abolish the fictional character of the work, carry the tale beyond the realm of tales, beyond the world of the literary work, and restore Alaryel's adventure to the everyday reality of the creative subject's sufferings and dilemmas]. The dramatic framework that was created in this manner becomes "istotnym narzędziem komunikacyjnym wynoszącym tekst do rangi świadectwa, wyznania, auto-egzorcyzmu" [an important instrument of communication, elevating the text to the status of testimony, a confession, a self-exorcism].$^{28}$ It should be pointed out, though, that whereas the dramatic subject emerging from the stage directions presents a particular viewpoint - a perspective that undermines the fictionality of the work - that fictionality is not negated completely in this particular work. This observation may come as a surprise, in particular if we remember that the dramatis personae do not have their own voice, since power over the word was taken away from them by the dramatic subject for the sake of - as Leśmian himself

${ }^{26}$ B. Leśmian, Skrzypek opętany, 61.

${ }^{27}$ Ibid., 60.

${ }^{28}$ W. Wołowski, Didaskalia i didaskaliczność $w$ dramacie $i$ nie tylko (Lublin: Wydawnictwo KUL, 2016), 103. 
puts it - the domination of stage action which constitutes the principle, the essence, and the purpose of this drama.

In theory, The Possessed Fiddler is a specific kind of dramatic work which presents the process of the dramatic subject's self-observation through the dramatic microcosm. This hypothesis logically leads to the conclusion that Leśmian's entire drama is a zero viewpoint space - the space of observing one's own sense of sight. However, in my theoretical reflection I have demonstrated that this specific "zero position" is the effect of the overlap of two points of view. Contrary to initial intuitions, then, one should consider the second component of the mechanism in question.

The world of The Possessed Fiddler is a realm of illusory boundaries. This is already made clear by the first "stage guidelines." The room in Alaryl's cottage is filled with objects that are seemingly useless and random, but prove indispensable for the events and actions of the fable. This room breathes the unintended splendour of a palace mixed with the enforced poverty of a peasant's cottage. The door covered with a black curtain is like a black canvas stretched on an easel, and the tall, floor-to-ceiling window lets in the trees of an ancient forest. Only in that kind of space is Chryza's dance made possible - "taniec wnętrzny, rytmicznie natężonych, pełen fal nagłych, ruchów i odruchów, a jednocześnie znieruchomień, zastanowień i zaczajeń...” [an inner dance, rhythmically intense, filled with sudden waves, movements and impulses, but also with pauses, reflections and lurking...]. This is supplemented by quiet music without noises that appears and disappears in the distance - like an eternal, flowing rhythm of existence. It is a world in the process of creation, dynamically split in two like the curtains between which there comes the Witch, the Undine, and the Shadow of Chryza.

The addressee is confronted with a world that cannot be "captured" at the moment of "incarnation." One should note that all of the persons of the drama (except for Alaryel and Chryza) appear as a result of doubling or splitting, but it is impossible to unequivocally reproduce the process in which it happens. Any attempt to describe the viewpoint that creates the dramatic microcosm is bound to prove a failure. This is a paradox - particularly since it is the gaze/ sight that is used as the main tool for initiating, creating, and modifying relations between the protagonists. Alaryel's eye "spotyka się ze spodziewanym spojrzeniem" [meets the expected gaze] of the Undine. Chryza is "znieruchomiona spojrzeniem" [immobilised by the gaze] of her rival and reacts as follows: "zagląda jej w oczy, jakby chciała dokładnie odbić się w tych oczach i napełnić je po brzegi swym odbiciem" [she looks her in the eyes as if she wanted to reflect all of herself in them and fill them to the brim with her reflection]. The gaze of the snake "oślepia zaś swoim blaskiem oczy" [blinds the eyes of] the Witch and the dwarves. Lines, perspectives, and viewpoints interpenetrate. On the one hand, 
the gaze gives the protagonists hope to discover and perhaps constitute themselves; on the other, it becomes a weapon against the others. Silence and absence of words does not allow the emerging relations to become established; each of them flares up like the indigo light and is gone immediately afterwards. There is no way we could ever hear the last sound of the song that Alaryel tries to decipher from the Undine's dress.

The device that Leśmian uses in The Possessed Fiddler is surprising and seems to transcend the boundaries of one particular dramatic piece. By depriving the persons of his drama of their voice, of the possibility of translating the rhythm of gazes into the rhythm of words, utterances, and of the story they form, the poet makes it impossible for the addressee to adopt the viewpoint of any of the protagonists. The addressee is therefore perforce restricted to an external, off-stage view of the dramatic microcosm. In theory, the author offers his reader a perfectly neutral viewpoint of the presented world. The lack of spoken word adds dynamics to the stage situation, which cannot be contained within the convention of a tableau vivant (which in this context should perhaps be re-defined), and negates all stasis.

The addressee of The Possessed Fiddler must not forget, however, that in this context there is only one "figure" that wields power over the word, since it has its own voice. The dramatic subjec - the one speaking through the stage directions that provide the framework for the text - does not act but speaks. By speaking, the subject forms the dramatic microcosm and thus allows the protagonists to act while remaining silent ${ }^{29}$ It is only at the intersection of voice and silence, speech and sight, that the dramatic world proper fully comes to life. In this way the dramatic subject is allowed to speak as if from inside the represented world. His words make it possible to follow the story of Alaryel and Chryza from the inside. This perception only becomes possible, however, at the moment when his voice has been located in the world of the play.

To conclude my comments on The Possessed Fiddler, let me recall the suggestions Leśmian makes concerning the Shadow of Chryza. The poet is aware that "ktoś może zapytać, dlaczego tylko Chryza posiada ów przywilej cienia, podczas gdy inne osoby Baśni zostały pozbawione tego przywileju" [someone could ask why only Chryza is given the privilege of having a shadow, while the other figures of the Fable are deprived of it]. For Leśmian the answer is simple: the playwright "zastanawia się nad cieniem Chryzy, zaś pomija milczeniem cienie innych osób, jakby tych cieni wcale nie było" [ponders upon the Shadow of Chryza but ignores the shadows of others, as if they did not exist].$^{30}$ This reply,

29 "W dramatach mimicznych wszystko, co milczy, może być osobą działającą" [In mimic dramas everything that is silent can also be an acting person] (B. Leśmian, Skrzypek opętany, 127).

${ }^{30}$ Ibid, 128. 
in the context of what I stated above, seems to be significant as a clue to the organising principle of the entire drama. Only by placing the voice of the dramatic subject inside the world of the drama was Leśmian able to turn the mime into a fully-fledged dramatic picture - the very antithesis of a tableau vivant.

\section{Tadeusz Różewicz - Putapka [The Trap]: Silence within the word}

Almost everything has already been written about Tadeusz Różewicz's mimetic and diagetic experiments. The stage directions for Kartoteka [The Card Index] and Akt przerywany [The Interrupted Act] are to this day one of the most characteristic examples of the changes that took place in Polish drama in the $20^{\text {th }}$ century. Among this multitude of stage experiments, however, we tend to overlook the drama that provides a fine example of Różewicz's surprising narrative strategy - a strategy that can be considered a mirror reflection of Leśmian's technique as analysed above.

The composition of this drama, titled The Trap, is determined by intersections of voice and silence. However, Różewicz draws these lines differently than Leśmian. The effect is stunning. Grzegorz Niziołek claims that it is in The Trap that:

proces rekonstrukcji dramatu wydaje się dobiegać [...] końca, a słowo odzyskiwać moc wyrażania wewnętrznych doświadczeń, inicjowania dialogu i oddziaływania, a konwencje teatralne nie są bezustannie obnażane i podważane. [...] Rozpadająca się rzeczywistość odsłania zarysy całości, różne perspektywy widzenia ludzkiego losu [...] nakładają się i przecinają. Ruchome jak gra napięc między bohaterami [the process of the reconstruction of drama seems to reach [...] its final point; words regain the power of expressing inner experience, initiating dialogue, and exerting impact. Theatrical conventions are no longer constantly exposed and undermined [...]; the reality falls apart, revealing an outline of the whole. Different perspectives on human fate $[. .$.$] overlap and intersect. They shift like the interplay of tensions among the persons of$ the drama.$^{31}$

It is therefore no wonder that in their research on The Trap, many drama analysts focused on the continuous interplay of viewpoints. It is a game that also translates into the realistic and poetic character of this work. ${ }^{32}$ Scholars confront the perspectives of Franz and the Father, Franz and Felice, Franz and Max. ${ }^{33}$

${ }^{31}$ G. Niziołek, "Ojcze nasz, któryś jest,” in idem, Ciało i słowo. Szkice o teatrze Tadeusza Różewicza (Kraków: Wydawnictwo Literackie, 2004), 249.

${ }^{32}$ A. Krajewska, "Różewicza sztuki splątane. Interpretacja performatywna," in Tadeusz Różewicz i obrazy, ed. A. Stankowska, M. Śniedziewska and M. Telicki (Poznań: Wydawnictwo Poznańskiego Towarzystwa Przyjaciół Nauk, 2015).

${ }^{33}$ M. Sugiera, "Kafka w oczach Różewicza," in Zobaczyć poetę: materiaty konferencji "Twórczość Tadeusza Różewicza,” ed. E. Guderian-Czaplińska, E. Kalemba-Kasprzak (Poznań: Wydawnictwo WIS, 1993). 
They look for moments in which the main protagonist looks at himself. ${ }^{34}$ They recreate the main thread of tensions between the unbridled physicality/carnality of this drama and its poetic dimension. ${ }^{35} \mathrm{But}$ in the course of this poetic-historical research they have failed to discover the source of Różewicz's composition strategy - that more or less mythical zero point. I do not claim that my own reflections can achieve this goal; nevertheless, by asking the question concerning the construction of the zero point I am making an attempt to take a closer look at the strategy in question.

One of the most striking features of The Trap is that most of its persons feel an uncontrollable need to speak out. Unlike the protagonists of The Possessed Fiddler, Franz, Max, Greta, and Felice can speak, have power over words, and even the ability to create a microcosm. Throughout the text one can find passages whose main purpose is to present the conflict between different points of view. Untypically of Różewicz's poetics, the stage directions woven into the text seem mainly to serve the creation of a typically stage-performative background for the dramatic conflicts between the persons of the drama. In this context, the recipient must be puzzled by Image $X$, which stands out from the above outlined structure of The Trap:

Na tle czarnej ściany, w głębi pojawiają się oprawcy. Ubrani w czarne uniformy... Pies policyjny na smyczy. Przechodzą szybko pod ścianą, potem słychać naszczekiwanie psa. Nikt ich nie zauważył. Valli i Elli szepcą do siebie, wybuchają śmiechem. Ottla przycina sekatorem gałązki. Franz budzi się, nasłuchuje. [...] Strażnicy-oprawcy mają prawo wkraczać na scenę w każdej chwili. Mogą przechodzić w milczeniu, ale mogą też zatrzymywać się przed wybranymi osobami [Against a black wall, upstage, there appear the executioners. Dressed in black uniforms... A police dog on a leash. They walk quickly along the wall, then you can hear the dog bark. Nobody has noticed them. Valli and Elli whisper to each other and burst out laughing. Ottla cuts the branches with clippers. Franz wakes up and listens. [...] The guards-executioners have the right to enter the stage any moment. They can walk in silence, but they can also stop in front of any persons they choose]. ${ }^{36}$

In this part the stage directions do not lose their basic function, which is to organise the dramatic background for the action. All the same, the construction

${ }^{34}$ FRANZ: "Chciałem się przed Tobą odznaczyć, okazać siłę woli, zwlekać z listem do Ciebie" ["I wanted to distinguish myself in your eyes, to show my willpower by putting off writing a letter to you”]; FRANZ: "Ty jesteś w lepszej sytuacji, zająłeś prawie równorzędną pozycję: ożeniłeś się! Sam nie wiesz, jak wielkiego dokonałeś czynu... jesteś mężem... samcem broniącym gniazda... szczerzycie na siebie kły... a ja z podwiniętym ogonem uciekam do kąta" ["You are in a better situation; you won a nearly equal position for yourself: you married! You don't even realise what a great achievement that is... you are a husband... a male defending the nest... you snarl ferociously at each other, and I run away into the dark corner, with my tail between my legs"] (T. Różewicz, Pułapka, in idem, Teatr 2 (Kraków: Wydawnictwo Literackie, 1998, 353, 389).

${ }^{35}$ L. Dorak-Wojakowska, Poetyka cielesności w utworach dramatycznych Tadeusza Różewicza (Kraków: Księgarnia Akademicka, 2007).

${ }^{36}$ T. Różewicz, Pułapka, 372. All bold print was added by the author of the present paper. 
of this fragment must come as a surprise to an attentive reader. Spaces once colourful and complex are now replaced by a plain, black wall. The dramatis personae that emerge from this background seem to have a special connection with the accompanying space. The blackness of the wall seems to absorb all sound. For the first time in the drama silence falls, there are no words. This is a clear signal that the Executioners have been deprived of their voice. The "soundlessness" of their behaviour opens up a gap, an abyss between the line of the dramatic horizon and the space of dramatic action itself. Even more importantly, once accepted, this strategy is consistently applied by the playwright.

Na scenę wchodzi Oprawca. Wskazuje na Ottlę. Franz tego nie widzi, układa w koszyku jabłka. Ottla zdziwiona dotyka dłonią piersi, jakby chciała zapytać "czy ja... czy to chodzi o mnie..." Oprawca kiwa głową... Ottla wygładza dłońmi bluzkę i spódnicę, na palcach odchodzi za Oprawcą. Idą wzdłuż czarnej ściany, giną w ciemności. Franz nie widzi tego, co dzieje się za jego plecami, na tle czarnej ściany. W dali rozlega się ujadanie psów [The Executioner enters the stage. He points to Ottla. Franz does not see it, he is putting apples in the basket. Ottla, surprised, touches her chest with her palm, as if she wanted to ask: "Me? Do you mean me?" The Executioner nods his head. Ottla smooths her blouse and her skirt with her hands, and tiptoes out of the stage behind the Executioner. They walk along the black wall and disappear in the darkness. One can hear dogs barking in the distance]. ${ }^{37}$

Franz can neither see nor hear what is happening around him. Still, it is at this very moment in the play that he seems to penetrate his own viewpoint and observes himself:

FRANZ

Odpycham sen, bo boję się, że prześpię życie, a teraz u Ciebie, na wsi chciałby czuwać przez całą noc i cały dzień... boję się, że prześpię, przegapię to, co najpiękniejsze. Cień pod jabłonią, światło na twojej twarzy, pianie koguta... boję się, że zasnę i kto mi to wszystko kolejno wykradnie... Przebudzę się w zamkniętej skrzyni albo szafie, gdzie pachnie mysimi odchodami, padliną [I am pushing sleep away because I am afraid that I might sleep through my life; and now at your place, in the country I want to stay awake all night and day... I am afraid to sleep through and miss what is most beautiful. The shade under the apple tree, the light on your face, the cockcrow... I am afraid that I will fall asleep and someone will steal all this from me... I will wake up in a locked chest or wardrobe smelling of mouse droppings and of carcass $].^{38}$

If we were to analyse this quotation in the context of Franz's other utterances in the play, it would perhaps not appear particularly striking. Still, in the composition of the entire Image $X$ it acquires a special meaning. The special semantics of this passage lies in the surroundings that are organised around the narration of the protagonist. Anna Krajewska suggests that comments in stage directions similar to those quoted above signal the impossibility of telling

\footnotetext{
${ }^{37}$ Ibid., 379.

${ }^{38}$ Ibid., 373.
} 
the story. ${ }^{39}$ However controversial this hypothesis might be, it expresses the conviction that the dramatic subject speaks through the stage directions. Paradoxically, this subject seems to apply a poetics of silence. It does not reveal itself directly; it conceals its own voice. Thanks to this device - the opposite of the strategy used by Bolesław Leśmian in Skrzypek opętany - Franz's voice seems to sound very different.

The clash between the dramatic horizon drawn by the silence of the dramatic subject and the stream of words coming from Franz opens up a space for the zero viewpoint. In this space lies the place assigned by Różewicz to the addresses of his work. It is a perspective that allows to move the thoughts of the main protagonist beyond the field of stage action, which was precisely defined in the drama until this point. How differently, in this context, do the words spoken by Franz sound: "to ja jestem pułapką, moje ciało jest pułapką, w którą wpadłem tuż po urodzeniu" [I am the trap; my body is a trap I fell into the moment I was born]. ${ }^{40}$

Incorporating the zero point of view in the analysis of the composition of The Trap reveals the dynamics of lyricism as reflected in the recurrent physicality of the represented world. A signal appears of the inextricable relation between the concrete and the metaphor. Różewicz does not, in any section of this text, suggest a subordination of one component of this relation to the other. On the contrary, he seems to constantly emphasise the relation between the reflections they constitute for one another. The source, the essence, and the purpose of this composition is the zero point of view.

Only when viewed against the background of all these relations, i.e. between Franz's point of view of Franz and the one determined by the dramatic subject, does a space open up for the figure of "the man with a book." Notably, even the historical narration concerning the camp (the only such direct one in The Trap) takes place at the intersection of two perspectives: those of the person/protagonist and of the text, which is not spoken but read. As was aptly pointed out by Irena Górska:

obraz, słowo i milczenie [...] przenikają się wzajemnie. Obraz nie może istnieć bez słów, a słowa bez milczenia. Konieczne jest zatem równorzędne traktowanie tych kategorii, ujmowanie ich w ciągłym ruchu, pokazywanie dynamiki, nieustannego przenikania się i wzajemnego warunkowania [image, word, silence [...] interpenetrate. Image cannot exist without words, and words - without silence. It is therefore necessary to treat both categories on equal terms, to present them as constantly shifting, to bring out their dynamics, their incessant interaction and mutual conditioning]. ${ }^{41}$

\footnotetext{
${ }^{39}$ A. Krajewska, "Różewicza sztuki splątane. Interpretacja performatywna."

${ }^{40}$ T. Różewicz, 375.

${ }^{41}$ I. Górska, "Między obrazem, słowem a milczeniem," in idem, Dramat jako filozofia dramatu na przykładzie twórczości Tadeusza Różewicza (Poznań: Wydawnictwo Naukowe UAM, 2004), 128.
} 
Only silence makes it possible for a full (though painful) relation between word and image to come to the fore; it inverts the perspective of reception and allows us to "zamieszkać we wnętrzu obrazu" [inhabit the inside world of the image]. ${ }^{42}$ In the case of The Trap, this inside world is the Wall of Death.

\section{Instead of a conclusion. Marian Pankowski - Biwak pod gotym niebem [Camping Rough]: The word within the word}

Let me conclude with a brief analysis of a fragment of a drama whose composition is entirely different from that of either Bolesław Leśmian's or Tadeusz Różewicz's works, but which nevertheless demonstrates a close relation to the former. In Camping Rough, Marian Pankowski tackles the issue of the sound of words, and of its meaning in the process of self-observation, conducted not only by the protagonists but also by the addressee.

In the context on the reflections as presented in this article, I would like to focus on one particular scene from Pankowski's play that relates directly to the title and is the key to its construction. It is in the scene of the Princes of the East camping rough close to Jerusalem, and not in the last passage of the text (as most researchers believe), that the source of this drama's semantics is to be found.

A few words of introduction: Pankowski's text is a curious modification of the nativity play genre; curious because it skips the crucial Nativity scene itself. ${ }^{43}$ The addressee of Camping Rough is confronted with a text which tells the story of the Wise Men heading to meet the Saviour. Pankowski shows them before and after their visit to Bethlehem. The very scene of paying homage to the Newborn Babe is not there. The author of Teatrowanie nad swietym barszczem [Theatralising Over the Holy Borsch] focuses on the nocturnal conversation of the Wise Men after they had met the Holy Family. After this discussion they depart and Caspar decides to go back to Bethlehem.

This conversation is characteristic for several reasons. It is one of the three scenes in this drama that take place in an open space. Most of the scenes take place in the house of Joseph, the palace of Herod, or in the streets of Jerusalem. Only this conversation, Maria and Joseph's escape, and the last scene are staged in spaces which are not clearly delineated. In the case of the night camp, this open space is emphasised in the stage directions and its meaning is reinforced by the title. The addressee gets the impression of being immersed in a conversation between the dramatis personae in a scenic void.

\footnotetext{
${ }^{42}$ K. Braun, T. Różewicz, Języki teatru (Wrocław: Wydawnictwo Dolnośląskie, 1989), 119.

${ }^{43}$ See K. Ruta-Rutkowska, “O dwóch dramatach Mariana Pankowskiego,” Ogród, no. 3/4 (1992).
} 
This void is further emphasised by the way the characters are described. Balthazar speaks of Caspar's unclosed eyes, and it seems that this expression applies to all three of them. Most important in this context is the question of what causes their eyes to remain wide open - for it is not only the miracle they have witnessed, as many might think. If this was the case, they would, as Caspar says, have gone blind, remained petrified. Instead, their eyes remain wide open. ${ }^{44}$

This opening of sight is caused by a confrontation of their expectations with what was supposed to remain invisible but turned out to be simple and true. And yet "nie można przyjść do Boga, powiedzieć 'dzień dobry' jego rodzicom i przyglądać im się jak zamorskim kupcom" [you cannot come to God, say 'good morning' to His parents and watch them as if you were watching merchants coming from overseas $]^{45}$ - and this is precisely what happened to Balthazar, Melchior, and Caspar. Meeting the Holy Family becomes, for them, a tinderbox for confronting their preconceptions with the image they found when they entered the shed in Bethlehem, and not so much even their own preconceptions as the narration that shaped them: "Noc... 'dziwna noc,' 'dziwni przybysze ze Wschodu'... rok podróży, gwiazdy i proroctwa..." [Night... "strange night," "strange travellers from the East..." a year of travelling, stars and prophecies...]. ${ }^{46}$

By removing the scene of paying homage to the Child, Pankowski lets the protagonists observe themselves. In order to understand the meaning of this device, we should go back to the ideas of Jacques Lacan as discussed in the opening section of this article. Only by removing the image from the space of the stage, by observing it "through the keyhole," can we also observe the relation between the gaze and the eye of the observer. It seems that this is the very process that the playwright from Sanok wants to initiate in the scene in question. One of Caspar's statements seems to point directly to such intentions of the author:

\section{CASPAR}

Tak, noc udziwnia i przydaje rzeczom tajemnicy, jak suknia ciału, ale my wiemy, że ciało odziane to nic innego jak tylko ciało i suknia... a skoro znamy i jedno, i drugie? [Yes, night makes all things seem strange and mysterious, like attire covering the body, but we know that a dressed body is nothing but just a body in clothes... and if we know one and the other, then what? $]^{47}$

At first they strongly oppose the process thus initiated. They do not want to acknowledge that their long trip was pointless, and Melchior and Balthazar suggest a different time frame ("a gdyby powrócić tu znowu... po latach" [and what

${ }^{44}$ See K. Latawiec, "Scena bożych kukieł," in idem, Na scenie świata i teatru. O dramaturgii Mariana Pankowskiego (Kraków: Universitas, 1994).

${ }^{45}$ M. Pankowski, Biwak pod gotym niebem, in idem, Dramaty (Warszawa: Wydawnictwo IBL, 2015), 74.

${ }^{46}$ Ibid., 75 .

${ }^{47}$ Ibid. 
if we came back here again... many years later]) and a different spatial frame ("ponowna nasza droga, powtórne zapukanie do drzwi tajemnicy" [to come all this way again and knock again on the doors of the mystery]). Caspar does not accept these solutions. Instead, he confronts his preconceptions with the experience of the miracle:

\section{CASPAR}

[...] boli mię, że przez lata lepiłem go z zachwytów młodości, niespełnionych pragnień, z niewiedzy i wiary... a teraz spojrzę na niego... wyrozumiale. A to uśmierca bogów [[...] it pains me that for years I moulded him out of youthful enchantment, of unfulfilled desires, lack of knowledge and faith... But now I will look at him... with understanding. And this kills gods]. ${ }^{48}$

The protagonist realises that the only way out of the situation is to enter the space of free and doubting thought. The dramatic composition that Pankowski uses here works as follows: in the first part the addressee adopts the Princes' point of view. He experiences the dramatic reality from the perspective of the narration of great biblical expectations, which, though confronted with the ironic remarks made, for instance, by Joseph's brothers, still does not lose its "power to create images." By leaving out the key scene of the Princes' homage to the Infant, the author of Camping Rough creates a situation that is similar to that described by Lacan. The protagonists describe the Nativity scene in such a way that the addressee gets the impression of catching glimpses of something of which only fragments can be seen. The dramatis personae make comments regarding their own expectations, which disrupts our process of observation, as pointed out by Lacan in his essay. The addressee is confronted with a structure of communication which resembles that of an anamorphosis. Thanks to a unique combination of narration about the image with remarks on the way its perception is conditioned, Pankowski opens up a space in which one can observe one's own gaze, one's own process of viewing. In this context the following utterance by Caspar gains unique significance:

\section{CASPAR}

Mędrcyśmy, a żal nam drogi darmo przebytej, jak ludziom u schyłku życia żal lat przeżytych... Jak inni lękamy się robactwa czy popiołu, co po nas pozostanie... i dlatego wierzymy, dlatego twierdzimy... że tak długiej drogi nie można przebyć bez sensu... że wszystko jest po coś. I chcemy nadal iść, nadal wierzyć... aby nadal móc drżeć na myśl o myśli, której daliśmy na imię "Bóg" [We are the Wise Men, and yet we regret having come this far, as old people regret the years they have lived... Like others we fear the vermin and dust that will remain of us... and this is why we believe, this is why we say that coming a long way is never pointless... that it has all been for a reason. And we want to keep walking, and still believe... so that we can still remain in awe of the thought that we call "God"]. ${ }^{49}$

\footnotetext{
${ }^{48}$ Ibid., 83.

${ }^{49}$ Ibid., 76.
} 
This passage should be treated as an expression of a peculiar kind of self-observation performed by a person of the drama. It is the word encapsulated in another word, a seeing of oneself in a dramatic light. This is the moment when the space of the zero viewpoint opens up. An act of self-perception links the addresser to the addressee. Caspar's words are unique because they combine the perspectives of the addresser, protagonist, and addressee of the text. Dramatic narration is one that is born at the dramatic zero point - at the moment when drama becomes a tale about viewing; about an act of viewing which is, it must be stressed, inimitable, because it is not limited to metatheatrical remarks attributed to the dramatic subject, a protagonist's self-reflective monologue, or lines addressed directly ad spectatorem. In drama, and possibly only in this literary kind, it is possible to create a special field of perception that results from an intersection of the lines of perception of the addressee, the addresser, and the protagonist. No wonder then that it is in this genre that the concept and question of viewpoint was born.

\section{Sum mary}

The author discusses the question of the so-called zero viewpoint in the context of the presence of epic elements in the dramatic text. Using the category of perspective in her study, she observes that one of the characteristic features of drama is the intersection of dramatic background and the protagonist's perspective. Contrary to the traditionally accepted view, the author argues that it is natural for drama to position the addressee not simply outside or inside the dramatic microcosm but at the point of a permanent intersection of these two lines. It is this moment of overlap between the extra- and intra-textual perspectives that she defines as the zero viewpoint. The variety of solutions by means of which this perspective can be achieved is demonstrated on excerpts she analyses from Bolesław Leśmian's The Possessed Fiddler, Tadeusz Różewicz's The Trap, and Marian Pankowski's Camping Rough.

\section{O ZEROWYM PUNKCIE WIDZENIA W DRAMACIE}

\section{Streszczenie}

Autorka artykułu, podejmując problematykę obecności w tekście dramatycznym elementów o charakterze epickim, rozważa zagadnienie tzw. zerowego punktu widzenia. Wprowadzenie w obszar rozważań kategorii perspektywy pozwala jej dostrzec, że jednym z charakterystycznych wyznaczników utworu dramatycznego jest przecięcie linii scenicznego tła i perspektywy bohatera. Wbrew tradycyjnym rozpoznaniom, autorka artykułu zakłada, że naturalne dla dramatu jest nie tyle sytuowanie pozycji odbiorczej na zewnątrz bądź wewnątrz scenicznego mikrokosmosu, ile nieustanne przecinanie się tych dwóch linii. To właśnie moment nałożenia się zewnątrz- i wewnątrztekstowej perspektywy autorka definiuje jako zerowy punkt widzenia. Różnorodność rozwiązań, za pomocą których można go osiągać, autorka stara się wykazać w trakcie analizy Skrzypka opętanego Bolesława Leśmiana, Pułapki Tadeusza Różewicza oraz Biwaku pod gołym niebem Mariana Pankowskiego. 